\title{
Cirkevné reálie v slovenských a českých prekladoch z ruskej literatúry 19. a 20. storočia
}

\section{Religious Realia in Slovak and Czech Translations from Russian Literature of the 19th and 20th Centuries}

Dušan Tellinger

(Košice, Slovenská republika)

\section{Abstrakt:}

Predmetom príspevku je skúmanie cirkevných reálií $\mathrm{v}$ slovenských a českých prekladoch a otázka ich preložitelnosti. Preložitelnost všetkých druhov sakrálnych/cirkevných textov (nielen umeleckých textov) závisí od kultúrnej, jazykovej a štylistickej kompetencie prekladatela. Existujú dve základné stratégie prekladu - odcudzovanie $\mathrm{v}$ protiklade $\mathrm{k}$ zdomácňovaniu. Odcudzovanie má ten zásadný ciel, aby si text s teologickými hodnotami zachoval cudzí charakter pre príjemcu prekladu. Naproti tomu zdomácňovaním sa stáva text prekladu plynulým na čítanie v cielovej kultúre. Ani jedna z týchto dvoch stratégií nie je zárukou pre vznik zdarného prekladu, preto sa prekladatel' snaží dosiahnut kreolizáciou kultúr a jazykov kompromis medzi obidvoma zmienenými stratégiami prekladu.

\section{Klúčové slová:}

preložitelnost'; cirkevné reálie; informačné pozadie; komentovanie reálií; kultúrna kompetencia; odcudzovanie; kreolizácia; pravoslávna liturgia

\section{Abstract:}

This paper reflects not only the issues of the research of the topic religious realia in Slovak and Czech translations but also their translatability. The translatability of all 
kinds of sacral/religious texts (not only literary texts) depends on translator's cultural, language and stylistic competence. A translator of texts which contain religious realia needs a specific strategy to bridge the gap between different religions, cultures and languages. There are two basic strategies-foreignization versus naturalization. The basic idea of the foreignizing strategy is the effort to make the text with theological values foreign to the target culture. In contrast naturalizing strategy makes the sacral/religious text fluent to the target culture reader. None of these two basic strategies is a guarantee of a successful translation therefore the translator's effort is a creolized culture and language in translation (i.e. a compromise strategy between both mentioned basic translational strategies).

\section{Key words:}

translatability; religious realia; background knowledge; comments on realia; cultural competence; foreignization; creolization; Orthodox liturgy

Liturgickému názvosloviu a cirkevným reáliám vo všeobecnosti sa venuje v teórii prekladu značná pozornost', ako o tom nachádzame vyhranené stanovisko i v nemeckej translatológii. Teologickým textom venuje pozornost’ predovšetkým Radegundis Stolzeová, ktorá pri ich preklade zdôrazňuje solídne vedomosti prekladatela z danej oblasti: „Auch theologische Texte werden Fachübersetzern vorgelegt und sie bieten aus übersetzungswissenschaftlicher Sicht vergleichbare Verstehensprobleme. Sie setzen ein theologisches Vorverständnis voraus, ohne welches bestimmte Begriffswörter, ja oft eine ganze Argumentation, nicht verständlich sind. Für Übersetzer mit theologischer Vorbildung besteht natürlich kein Verstehensproblem“1 . Úspešnosț prekladu religióznych textov je založená na správnom pochopení termínov a reálií. Vychádza sa z princípu konfesionality, ktorý sa nezriedka dodržiava i na úkor zrozumitelnosti termínov a reálií. Nezanedbatelnú úlohu pri preklade teologických textov zohráva príslušnost̉ prekladatela k určitej konfesii (krestanstvo, judaizmus, hinduizmus, islam), čiže k určitému kultúrnemu okruhu. Problematika prekladu tejto úzko špecializovanej lexiky súvisí s konfesionálnym povedomím kultúrneho spoločenstva, pre ktoré preklad vzniká. $Z$ potrieb veriacich každého kultúrneho spoločenstva aj vyplýva nevyhnutnost̉ prekladania religióznych textov. Iná je však

1 „I teologické texty sa ponúkajú odborným prekladatelom a tieto texty predstavujú porovnatelné problémy ich pochopenia $\mathrm{z}$ hladiska vedy o preklade. Sú potrebné pre ne predbežné teologické vedomosti, bez ktorých nie sú pochopitelné niektoré označenia pojmov, no často i celá argumentácia. Pre odborného prekladatela s predbežným teologickým vzdelaním samozrejme neexistuje problém pochopenia." (preklad D. T.) STOLZE, R.: Fachübersetzen - Ein Lehrbuch für Theorie und Praxis. Berlin: Frank \& Timme, 2013, s. 101. 
situácia pri preklade umeleckej literatúry so silnou vrstvou lexiky z náboženského prostredia - cirkevných reálií, čo sa v československých pomeroch prejavilo najmä v období od spoločenského prevratu, ked’ sa začali prekladat i diela ruských autorov, ktoré boli opomínané pred rokom 1989. V súvislosti s touto problematikou hovorí tretia česká prekladatelka Gogolovho diela Размышления о Божественной литургии (Rozjímání o božské liturgii - 1996) Zdeňka Vychodilová o dvoch nasledovných lexikálno-sémantických skupinách reáliových výrazov, ktoré sa vzṫahujú na opis svätej liturgie: „I. tzv. bezekvivalentní lexikum - př́pady, kdy v reáliích cílového jazyka, tedy češtiny, neexistuje odpovídající věcný ekvivalent, napřs: иконостас ikonostas, амвон - ambon, жертвенник - žertveník, проскомидия - proskomidie a jiné. II. funkční ekvivalenty - v odpovídající mimojazykové situaci analogického západního obřadu existují prredměty či jevy plnící podobnou funkci. Jde však vždy o částečnou ekvivalenci, kde částečnost postihuje především významové denotační rozdíly, např.: фелон - felon (svrchní kněžské roucho - odpovída římské kasuli), cтuхapb - stichar (kněžské roucho, obvykle bílé, odpovídající latinské albě), нарукавнищы - narukavnice (manžety, odpovídají latinskému manipulu) a dalši “2 ${ }^{2}$ Pochopenie liturgického procesu v Gogolovom diele je založené na správnom preklade termínov a reálií súvisiacich napr. s obradným rúchom $\mathrm{v}$ českom jazykovom prostredí. Aby si čitatel ruskej klasiky dokázal uvedomit rozdiely $\mathrm{v}$ jednotlivých komponentoch rúcha kňazov gréckobyzantského a rímskeho ríta, nestačia iba komentáre, ktoré pripájajú niektorí prekladatelia beletristických diel k týmto cirkevným reáliám.

V publikáciách slovenského lexikológa Štefana Švagrovského sa mimoriadna pozornosṫ venuje porovnaniu gréckobyzantského a rímskeho rítu - i pri opise už stručne spomenutého rozdielu bohoslužobného rúcha východnej a západnej cirkvi: „Kňaz, ktorý sa chystá slúžit sv. liturgiu (omšu), si oblieka na čierny talár najprv stichar, svetlú dlhú košelu (u rímskeho rítu alba). Obliekajú ho diakoni, kňazi i biskupi. Stichar sa prepáše pásom z látky (u rímskeho rítu cingula). Na konce rukáva sticharu sa navliekajú nárukavníky - epimanikie. Diakon si oblieka na stichar ešte diakonskú štólu, orár, dlhý úzky pruh látky okolo krku, splývajúci po oboch stranách. Kňaz i biskup obliekajú na stichar epitrachyl (u rímskeho rítu štóla) - je to dvojitý vyšívaný pás látky siahajúci až k nohám, avšak na rozdiel od štóly je spojený. Na epitrachyl potom kňaz oblieka felon (u latinského rítu kazula), ktorý siaha vpredu len k pásu, takže dole od pásu vidiet' obidva spojené konce epitrachylu. Biskup namiesto felonu oblieka sakkos (doslova vrece), čiže vrchné biskupské rúcho. Naň si ešte kladie biskup omofor, široký pruh látky okolo ramien, splývajúci na prsia a na chrbát (je to obdoba pallia u rímskeho rítu). Odznakom biskupa je tiež nábederník, tuhý látkový kosoštvorec, ktorý si biskup

2 VYCHODILOVÁ, Z.: Několik poznámek k prekladu religiózní literatury. In: LEPILOVÁ, K. (ed.): Rossica Ostraviensia '96. Lingua rossica in sphaera mercaturae. Ostrava: Filozofická fakulta Ostravské univerzity, 1996, s. 249. 
pripína k pásu po pravej strane. Pri archijerejskej liturgii (pontifikálnej omši) má biskup na hlave mitru, biskupskú čiapku, ktorá však nemá podobu dvojdielnej pokrývky hlavy s vybiehajúcimi hrotmi, ale korunky, ukončenej hviezdou."3

Pri preklade umeleckej literatúry badat’ vo všeobecnosti značnú mieru volnosti v prípade cirkevných reálií, aby boli zrozumitelné čitatelom i bez dlhých komentárov. Stretnutie východnej a západnej kultúry vidiet’ práve na spôsoboch prekladu cirkevných reálií, kde prichádzajú do úvahy dva základné princípy - ponechávajúci a nahradzujúci (v odbore prekladatel’stva známe ako protiklad naturalizácie a exotizácie). Ide o preklady z ruštiny do dvoch jazykov v interkultúrnom jazykovom prostredí, v ktorom od najstarších čias dominuje latinská cirkevná terminologická tradícia. Bohatý materiál na obidva princípy poskytujú preklady románu Пошехонская старина M. J. Saltykova-Ščedrina do slovenčiny a češtiny. Tak napr. епархиальный архиереŭ je v preklade Márie Rázusovej-Martákovej (1905 - 1964; dalej iba M. R.-M.), ktorý vyšiel pod názvom Kocúrkovská starina v roku 1951, ponechaný v pôvodnom tvare - eparchiálny archijerej (a k tomu prekladatelkina vysvetlivka pod čiarou diecézny biskup). V obidvoch českých prekladoch, ktoré vyšli pod rovnakým názvom Pošechonské staré časy, je prispôsobenie tejto reálie domácim pomerom. V preklade Anny Teskovej (1872 - 1954; dalej iba A. T.) (vyšiel opätovne posmrtne v r. 1955) diecésní biskup (a v poznámkach - na konci knihy: Archijerej - obecný, neoficiální název pro biskupa, arcibiskupa, metropolitu). V preklade Jaroslava Huláka (1920 - 1999; dalej iba J. H.) a Sergeja Machonina (1918 - 1995; dalej iba S. M.), ktorý však nie je uvedený v knihe, pretože v 7o. rokoch nesmel publikovat (ich spoločný preklad je z roku 1976) biskup - bez komentovania. Naproti tomu dalšie cirkevné hodnosti npomonon a non sú vo všetkých porovnávaných prekladoch ponechané - bez komentára. Menej známe дьячок sa nahrádza domácimi ekvivalentmi: Наш поп был полуграмотный, выслужившийся из дьячков. - Náš pop bol pologramotný a vyškriabal sa z kostolníka (M. R.-M.). - Náš pop uměl trochu psát a číst a na popa to dotáhl z kostelníka (A. T.). - Náš pop byl pologramotný, vypracoval se na popa z žalmisty (J.H.).

$\mathrm{V}$ preklade A. Teskovej sa aspoň v určitej miere komentujú cirkevné reálie, no napriek tomu pochopia čitatelia mnohé fakty len na základe svojej erudície. Tak napr. v kapitole románu, kde sa hovorí o narodení autora a jeho súrodencov, je zmienená i náboženská stránka pôrodu: В крайнем случае во время родов отворяли в церкви царские двери, а дом несколько раз обходили кругом с иконой. V krajnom prípade za pôrodu otvorili sväté dvere a s ikonou obišli dom niekolkokrát dookola (M. R.-M.). - Když bylo zle, otevřeli v dobe porodu ,královské dveře' v kostele a obcházeli několikrát s ikonou dům (A. T.). Na konci knihy je i komentár: Královské

3 ŠVAGROVSKÝ, Š.: Gréckobyzantský rítus na území Slovenska. Slavica Slovaca, 33, 1998, č. 2, s. 104. 
dveře - prostrední dveře v ikonostasu. Ikonostas je stěna s obrazy svatých a s trojími dveřmi. (Severní se jmenují jáhenské, jižní palamarské.) Ikonostas odděluje kněžiště od chrámové lodi. V preklade J. Huláka je náhrada ikonostasu oltárom (podobne ako na inom mieste románu analoj nahradil oltárikom): Nanejvýš ještě někdy přímo při porodu otvírali v kostele dveře před oltářem a párkrát obešli dům s ikonou. Táto čast̉ ikonostasu sa spomína v románe aj neskôr: Поп порывался затворить царские врата. - Рop sa pobral zatvorit sväté dvere (M. R.-M.). - Pop se hrnul zavř́t královské dveře (A. T.). Pop chtěl mermomocí zavř́t oltářní dveře (J.H.). Vo všeobecnosti platí, že pri preklade spomenutých slov pomenúvajúcich cirkevné reálie siahajú prekladatelia najčastejšie $\mathrm{k}$ lexikálnym prostriedkom (teda nie $\mathrm{k}$ tzv. nulovému prekladu, to jest $\mathrm{k}$ sémantickému prekladu tzv. nepreložitelných slov na úrovni celého textu): „transkripcia, transliterácia, adaptovanie reálií, tvorenie neologizmov a kalkov, ktoré predstavujú zdanlivo ich najjednoduchší preklad."4

Podrobnú informáciu o vnútri ruského chrámu s ikonostasom i o troch dverách v ňom poskytuje Š. Švagrovský: „Vnútro chrámu tvorí predsien̆, cez ktorú sa vchádza do vlastného chrámového priestoru. Ten je rozdelený na lod' a kňažište (oltárnu čast'). Lod’ je od kňažišta oddelená ikonostasom, na ktorom sú v presnom poradí usporiadané ikony svätcov. V ikonostase je troje dverí: stredné dvojdielne sa nazývajú královské, cez ktoré môže do kňažišta vstupovat len klérus. Pred královskými dverami je umiestnený prestol (obetný stôl). Ďalej sú v ikonostase tzv. severné a južné dvere - severnými sa vchádza do priestoru určeného na prípravu obetných darov, južnými do priestoru, ktorý je vyhradený pre diakonov. V oltárnej časti chrámu, kňažišti, je obetný stôl štvorcového tvaru - prestol (trapeza) prikrytý zo všetkých strán až k podlahe, na ňom leží zložený antimins (u rímskeho rítu oltárny kameň) s ostatkami svätých, zabalený do ilitonu (u rímskeho rítu korporal) a evanjeliár. $\mathrm{V}$ pozadí prestolu je kríž a sedemramenný svietnik, pred krížom je umiestnená tzv. darochranitelnica (u lat. rítu tabernakulum), vežovitá schránka so sviatostou a olejmi. Je prenosná. Vlavo oproti severným dverám ikonostasu je menší oltár zvaný žertveník (u rímskeho rítu protesis), na ktorom sa začína bohoslužba prípravou obetných darov. Celý priestor oltára s ikonostasom je oproti chrámovej lodi vyvýšený asi o výšku jedného schodu a pred královskými dverami vybieha do polkruhu zvaného ambona. $Z$ tohto vyvýšeného miesta sa číta Sväté písmo a kňaz káže. “5 Už uvedené komentovanie cirkevných reálií poukazuje na to, akú dôležitost̉ má kultúrna kompetencia prekladatela, ku ktorej možno nájst’ nasledovné konštatovanie v nemeckej translatologickej literatúre, že je to „Kenntnis

4 TELLINGER, D.: Kultúrne otázky prekladu umeleckej literatúry. Košice: Typopress, 2005, s. 91.

5 ŠVAGROVSKÝ, Š.: Gréckobyzantský rítus na území Slovenska. Slavica Slovaca, 33, 1998, č. 2 , S. $103-104$. 
und Beherrschung von Kultur."6 Kultúrnu kompetenciu člení Heidrun Witteová na inom mieste svojej knihy na parakultúrnu, diakultúrnu a idiokultúrnu kompetenciu. ${ }^{7}$ Na nasledujúcich miestach knihy sa odvoláva autorka pri tomto aj na závery Franza Pöchhackera o internacionálnej diakultúre vo vzṫahu k translácii. ${ }^{8}$

$\mathrm{V}$ porovnávaných slovenských a českých prekladoch $\mathrm{v}$ tomto príspevku venovanom cirkevným reáliám možno rozlišovat dva základné postupy priblíženia ruských cirkevných reálií našim čitatelom:

1. Riešenia ponechávajúce, pri ktorých sa cudzí výraz preberá (tento postup je sprevádzaný neraz i s vysvetlivkou - bud pod čiarou, alebo vo forme textovej vsuvky - nezriedka aj s obšírnejším objasnením na konci knihy). Dochádza takýmto spôsobom i $\mathrm{k}$ určitému prispôsobeniu cudzieho slova normám prijímajúceho jazyka - $\mathrm{k}$ adaptácii. Ponechávajúce riešenia sú skôr typické pre generácie starších prekladatelov - akými boli osobnosti 19. a 20. storočia (A. Tesková - tvorivo činná už pred M. Rázusovou-Martákovou).

2. Riešenia diferencujúce, pri ktorých dochádza k nahradeniu (substitúcii) cudzieho prvku domácim ekvivalentom na základe určitej zhody dôležitých vlastností. Uplatňuje sa pri tomto postupe hlavne funkčný zretel’ - nahradzujúci výraz v cielovej kultúre spĺña podobnú úlohu ako pôvodný výraz v kultúre originálu, aj ked’ sa $\mathrm{v}$ určitých detailoch môžu reálie $\mathrm{v}$ origináli a v preklade neraz dost’ značne odlišovat'. Týmito riešeniami sa vyznačuje mnohostranná prekladatel'ská činnost̉ J. Huláka, ktorá sa uzavrela na konci 20. storočia prekladatelovou smrtoou. Ako príklad na protiklad ponechávajúceho a diferencujúceho riešenia môže poslúžit reália амвон: А по окончании службы поп выходил на амвон. - Ale po skončení bohoslužieb pop vyšiel na ambonu (M. R.-M.). - Po ukončení bohoslužby vystoupil pop na kazatelnu (A. T.). - A po bohoslužbách vycházel pop na kazatelnu (J. H.). Podobne je to i pri cirkevnej reálii аналой: То ставила среди комнаты аналой и ходила вокруг него с зажженной свечой, воображая себя невестой и посылая воздушные поцелуи Иосифу Прекрасному. - To postavila stred izby analoj a chodila okolo neho so zažatou sviecou, ako by bola mladuchou, a posielala vzdušné bozky Jozefovi Krásnemu (M. R.-M.). - Pak zase postavila doprostřed pokoje analoj a obcházela jej kolem dokola s rozžatou svící, představujíc si sebe jako nevěstu a posílajíc Josefu Spanilému vzdušné polibky (u A. Teskovej je objasnenie na konci knihy: Analoj - kostelní stolek s nakloněnou deskou; na něj se kladou posvátné knihy a ikony, kolem něho vodí kněz při svatebním obřadu ženícha s nevěstou). V preklade

6 „Znalost’ a ovládanie kultúry“ - preklad D. T. WITTE, H.: Die Kultukompetenz des Translators: begriffliche Grundlegung und Didaktisierung. Tübingen: Stauffenburg Verlag, 200o, s. 53.

7 „Para- Dia,- und Idiokultur(kompetenz/en)“ Porov. tamže, s. 55.

8 Porov. tamže, s. 57. 
J. Huláka je kompenzácia slova analoj: Tu si zas postavila doprostřed pokoje oltáŕíček a chodila kolem něho s rozžatou svící jako nevěsta a posílala vzdušné polibky Josefu Spanilému. Protiklad obidvoch riešení možno objasnit tým, že pri málo známych cirkevných reáliách je pri ponechaní reálie nevyhnutný komentár, ako to možno vidiet pri proskomidii: Он совершает проскомидию, как настоящий иерей. Odbavuje proskomidiu ako ozajstný kňaz. Prekladatelka pripája k tomu poznámku: Proskomidia (doslovne prinesenie), prvá čast̉ pravoslávnej liturgie. V obidvoch českých prekladoch je výraz zo západnej liturgie proměňování, čím odpadá potreba komentovat ho: Koná proměňování jako skutečný kněz (A. T.). - Dělá proměňování jako skutečný kněz (J.H.).

V jednotlivých situáciách prichádza do úvahy tak komentovanie, ako aj náhrada, napr. nросвира domácou reáliou hostia. Otec spisovatela Saltykova-Ščedrina vykonával v svojom kabinete liturgiu a rozdával nekonsekrované kúsky prosviry ako kňaz po liturgii: Отец каждое утро запирался в кабинет и, выйдя оттуда, раздавал нам по кусочку зачерствелой просвиры. - Každého rána sa otec zamykal v kabinete, a ked vyšiel, rozdával nám po kúsočku zatvrdnutej prosviry (v poznámke prekladatelky: Prosvira je hostia pravoslávnych z nekvaseného cesta). V českých prekladoch sa využíva spôsob ponechávajúci i nahrádzajúci: Otec se každého rána zamykal v kabinetě, a když pak vycházel, dával nám po kousíčku zatvrdlé prosviry (v komentároch na konci knihy: Prosvira - hostie z nekvašeného těsta). - Tatínek se každé ráno zavíral ve své pracovně, a když vyšel, poděloval nás kousičkem zatvrdlé hostie (J.H.). Táto reália si zasluhuje mimoriadnu pozornost’, pretože jej výskyt v románe sa dá využit na odlíšenie dvoch liturgií. Podrobne o prosvire (prosfore) vo východnej liturgii píše Š. Švagrovský: „Na začiatku svätej liturgie pristúpi kňaz k žertveniku (prothesis), ktorý sa nachádza za severnými dverami ikonostasu, a na ňom pripravuje obetné dary. Táto prípravná čast̉ sa nazýva proskomidia. Zvláštnym nožíkom, zvaným svätá kopia, vyrezáva z kruhovej prosfory (z kvaseného pšeničného chleba) strednú štvorcovú čast', nazývanú pečat alebo baránok s iniciálami IC-XC-NI-KA (Isus Christos nika fežiš Kristus vítazí). Do kalichu, ktorý je trocha širší než v západnej liturgii, nalieva víno a primiešava trochu vody. $Z$ dalších prosfor potom vyrezáva menšie čiastky v tvare kociek, ktoré v zvláštnom poradí (Matka Božia, za živých, za mŕtvych) kladie za príslušných modlitieb na diskos (paténu) miskovitého tvaru."9

Stretnutie dvoch kultúr predstavujú v slovenských a českých prekladoch z ruskej klasiky 19. a 20. storočia všetky cirkevné reálie, ktoré sú spojené s východným obradom a s náboženstvom vo všeobecnosti. Prekladatelia sa usilujú nájsţ pre ruské cirkevné reálie domáce analógy; vidíme to i v prípade slova богомол (nábožný človek), ktoré M. Rázusová-Martáková prekladá ako modleník - v ruštine má toto slovo ekvivalent

9 ŠVAGROVSKÝ, Š.: Gréckobyzantský rítus na území Slovenska. Slavica Slovaca, 33, 1998, č. 2, s. 105. 
молельщик (который читает первым молитву в костёле): В это время у нас в доме гостил мещанин - богомол Дмитрий Никоныч Бархатов, которого в уезде считали за прозорливого. - Vtedy bol hostom v našom dome meštan-modleník Dmitrij Nikonyč Barchatov, ktorého v obvode pokladali za jasnozrivého (M. R.-M.). V preklade A. Teskovej je použitý ekvivalent pútnik (zodpovedá ruskému bogomol): Toho času byl u nás na náštěvě poutník Dmitrij Nikonyč Barchatov, člověk z meštanského stavu, jehož v našem okrese pokladali za jasnovidného. V preklade J. Huláka je zovšeobecnenie: $\mathrm{V}$ těch dnech byl u nás hostem zbožný měštan Dmitrij Nikonyč Barchatov, muž, který měl v újezdě pověst jasnovidce. Možno niekedy na objasnenie málo známej reálie použit aj poznámku pod čiarou, napr. благочинный (что представлял собой благочинный) v preklade M. Rázusovej-Martákovej (čo znamená blahočinný - blahočinný - kňaz, ktorý má dozor nad niekolkými cirkvami). V preklade A. Teskovej je použitý domáci analóg (co to znamená děkan), resp. nachádzame aj opis tejto ruskej reálie v preklade J. Huláka (kto to je hlavní kněz). Ponechávajúci princíp sa prejavuje v porovnávaných troch prekladoch pri preklade typickej ruskej reálie раскольник: v preklade M. Rázusovej-Martákovej rozkolník - v obidvoch českých prekladoch sektár. Pri klúčovej postave Raskolnikova z Dostojevského románu Zločin a trest napr. dochádza k prekladatelskému problému, či objasnit slovenským a českým čitatelom význam zašifrovaný $\mathrm{v}$ mene tejto hlavnej postavy stelesňujúcej zlo popri iných záporných postavách Dostojevského tvorby (napr. v románe Besy, čiže diabli - bes v staroegyptskej mytológii bôžik zla a v ruskom folklóre podla starých národných povier zlý duch), ako to navrhuje učinit v komentároch pri takýchto výrazoch i odborníčka na preklad rozprávkových a cirkevných textov Eva Maria Hrdinová v svojej bohatej publikačnej produkcii, zameranej predovšetkým na výskum liturgického jazyka.

Bez dobrých kultúrnych znalostí nie je možný adekvátny preklad žiadnych cirkevných reálií, ani takých bežných, vyskytujúcich sa v sakrálnych textoch, ako sú slová pomenúvajúce zlo - napr. o gravírujúcich rozdieloch pri preklade nemeckého slova Teufel pojednáva E. M. Hrdinová pri prekladoch rozprávok: „Ako príklad by tu mohlo slúžit nemecké slovo Teufel vs. jeho české ekvivalenty čert a d’ábel. [...] Súhrne a zovšeobecňujúc možno teda povedat, že nemeckému slovu Teufel vo význame odporca boží či nemeckému slovu Satan zodpovedá české slovo d’ábel, ktorému prislúchajú ešte dodatočné konotácie: dáael ako sexuálne aktívny muž, záletník alebo smelý človek (porov. anglické slovo daredevil). České slovo čert zodpovedá síce diabolskej rozprávkovej bytosti, ktorá však v českých rozprávkach často vytupuje dobromyselne - kladne, a často i prehráva voči človeku, ale i predstavuje ekvivalent pre rakúske slovo Krampus (= čert, ktorý sprevádza sv. Mikuláša na deň sv. Mikuláša). Bokom ponechávame dalšie prevzaté, väčšinou biblicky fundované synonyma Dämon alebo Beelzebub, alebo taktiež rovnako väčšinou bezekvivalentné rakúske slovo 
Perchten. ${ }^{10}$ Práve slovo čert (Teufel) poskytuje podla E. M. Hrdinovej ${ }^{11}$ celým svojím radom synonymov v češtine a slovenčine široký priestor pre prekladatel'skú tvorivú invenciu - synonymický rad v češtine: čert, dábel, satan, satanáš, rohatej, antikrist, černý (černej), lucifer, luciper, d’as, čerchmant, belzebub, pekelník, rarach, diblík, plivník, rarášek (Gelddrache, Feuerdrache?)... Démon, d’ábel...; synonymický rad v slovenčine: čert (v rozprávkach), d’as, rohatý, ancikrist/anciáš, satanáš, lucifer, fras (fras - Fraisen, vezme si ta fras = dostaneš psotník, epilepsia bola svojho času považovaná za „pekelnú chorobu“), parom (teda Perún), rarach - rarášok (= zmok, Gelddrache/Feuerdrache?), belzebub... Diabol, démon..."

Širokú oblast̉ možností uplatnenia tvorivej invencie poskytujú prekladatelom cirkevné sviatky pravoslávia a pôsty (Филипповки, Петровки), ako i názvy sakrálnych objektov - chrámov a monastierov (Чудов монастырь, Сергиев посад, Новодевичий монастырь). Pri preklade názvov cirkevných sviatkov postupuje M. Rázusová-Martáková dvoma spôsobmi - ponecháva ich v ruskom znení, alebo niekedy používa i slovenské ekvivalenty. Ako príklad na ponechávajúci princíp možno uviest’ sviatok покров: Иногда с покрова выпадал снег и начинались серьезные морозы. Niekedy od Pokrova padal sneh a začalo poriadne mrznút'. V preklade A. Teskovej je k tomu objasnenie na konci knihy: Někdy již o svátku Panny Marie Pomocné napadl sníh a začalo pořádně mrznout. - Svátek Panny Marie - 1. října podle starého kalendáře. V preklade J. Huláka bez komentára: Někdy napadl sníh už na svátek Panny Marie Pomocné a uhodily pořádne mrazy. Prácu J. Huláka pri preklade cirkevných reálií možno taktiež podrobne sledovat pri tak významnom diele, akým je trojdielna epopeja Alexeja Tolstého Peter I. Táto pútavá kniha autora, ktorý podáva obraz o živote ruskej a západoeurópskej spoločnosti na prelome 17. a 18. storočia, je mimoriadne náročná na preklad všetkých skupín reálií, osobitne cirkevných reálií. Čitatelovi diela poskytuje nadaný spisovatel panoramatický obraz chrámov Moskvy a tradičného života ortodoxného duchovenstva. Možno porovnat riešenia pri preklade do slovenčiny a češtiny, ktoré poukazujú na väčšiu volnost̉ v preklade Jaroslava Huláka (1982) než v preklade Marty Ličkovej (1969): осьмиконечный крест - trojramenný kríž osmiramenný kř́ž; четырёхконечный крыж - dvojramenný kríž - kř́ž, jak má být; Варвара великомученица - Varvara velkoтис̌еníčka - Svatá Barbora; богомолье omša - poutní cesta; npocфopa - prosfira - hostie / svěcený chléb; лавpa - lavra - klášter; клобук - mitra - vysoká mnišska čepice; монашкин клобук / чёрный клобук - mпišsky

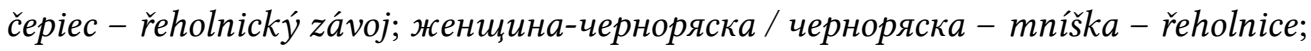
скуфья - mnišske rúcho - šlojír jeptišky; епuтрахиль - kutña - štóla; лествица -

10 HRDINOVÁ, E. M.: Von drei translatorischen Nüssen des Aschenbrödels. Zeitschrift für Slawistik, 63 (2018), s. $341-342$.

11 Porov. tamže, s. 341. 
kožený ruženec - ruženec; крестный ход - procesia - průvod; обедня - poludňajšia отša / отг̌a - тše; храм Иоанна-Предтечи - chrám fána Zvestovatela - chrám fana Krtitele.

Jedným z dôležitých prekladatel’ských postupov pri preklade reálií je kompenzácia, pri ktorej ide o reprodukciu pôvodnej informácie inými slovnými prostriedkami cielového jazyka. Vyžaduje si to určitú tvorivú invenciu prekladatela, ako je to aj v prípade J. Huláka, ktorý vetu z románu Peter I. (И крест пишем - крыж четырехконечный) neprekladá doslovne - je to až smerom k metafore: Kř́ž, jak má být. V preklade M. Ličkovej: A kríž malujeme dvojramenný. J. Hulák napriek určitej volnosti pri preklade nenarúša pôvodné významy cirkevných reálií chybami, ktoré by vyplývali z nedostatočnej oboznámenosti s dobovou realitou. Ako jeden z prejavov tejto malej skúsenosti s históriou pravoslávia je chybný slovenský preklad spojenia афонские чётки - aténsky ruženec (M. Ličková) - athoský ruženec (J.Hulák). Aj pri nemeckých prekladoch tejto cirkevnej reálie, ktorá sa vyskytuje v prvom diele Tolstého románu vydaného v Moskve roku 1929, je význam zachovaný bezchybne: $\mathrm{v}$ preklade Wolfganga E. Groegera (1931 Lipsko) Rosenkranz vom Bergkloster Athos - v preklade Maximiliana Schicka (1950 Moskva) Rosenkranz aus dem Athoskloster. Nemeckému čitatelovi ruského klasického diela bolo treba nejakým spôsobom napomôct', aby si reálie vedel vysvetlit. Ako príklad poslúži objasnenie dôležitej reálie ruského pravoslávia осьмиконечный крест $\mathrm{v}$ druhom nemeckom preklade - das Kreuz mit den drei Querbalken (M. Schick) - naproti tomu v prvom preklade je to doslovne achtzackiges Kreuz (W. E. Goeger).

O funkcii cirkevných (teologických) termínov, resp. vo všeobecnosti o rozdieloch medzi termínami a reáliami obšírne pojednáva E. M. Hrdinová v celom rade publikácií zameraných na preklad liturgie sv. Jána Zlatoústeho. V svojej aktuálnej knihe sa $\mathrm{k}$ terminologickej problematike súvisiacej s náboženským štýlom vyslovuje nasledovne: „S ohledem na překlad termínů je v této souvislosti zásadní adekvátní př̀vod odborních termínů a pro překladatele vyvstávající povinnost zachování terminologického charakteru z originálu i v př̀ekladu. Zatímco ještě starší translatologická generace se zaměřovala s ohledem na překlad odborného textu především na překlad termínů, zaměření současných prací se zaměřuje i na další jazykové roviny než jen lexikální, a to na syntaktickou a textovou. Tam se u překladu humanitně zaměřených textů často zdůrazňuje zejména větší blízkost $\mathrm{k}$ beletristickému stylu, než jak je tomu u odborných textů nehumanitního typu. Přesto však hledisko terminologické správnosti zůstává pro translaci odborných textů neopominutelné."12 Správnost’ výberu ekvivalentov pre termíny cirkvi byzantsko-slovanského obradu je podmienkou zachovania terminologickej osobitosti byzantskej liturgickej tradície. Je to zároveň

12 HRDINOVÁ, E. M.: Kultura v procesu prekladu. Olomouc: Univerzita Palackého, 2017, s. 18. 
i podmienka zachovania náboženského štýlu byzantsko-slovanského obradu. Cirkevné (teologické) termíny - ako napr. Boh a diabol - disponujú podla názoru autorky ${ }^{13}$ v humanitne zameraných (teologických) textoch rôznymi konotáciami; podobne je to i v prípade reálií. Najdôležitejšou funkciou cirkevných reálii je ako dôležité pravidlo pridat umeleckému textu autentičnost̉ a situovat ho v určitom historickom období.

Kedže tieto problematické miesta textu sú dost̉ tažko preložitelné, musíme si uvedomit ich funkciu v celkovom texte, ako o tom vo všeobecnosti hovorí popredný nemecký teoretik prekladu Paul Kußmaul: „Wenn wir dann problemhafte Textstellen vor uns haben, werden wir überlegen, wie sich die allgemeine Textfunktion auf die Funktion der jeweiligen Textstellen auswirkt." ${ }^{\text {"14 }}$ Pretože nejde o odborný preklad s presnými ekvivalentmi pre cirkevné reálie, ale o umelecký preklad s väčšou mierou slobodného prekladania cirkevných reálií, tak berieme do úvahy komplexnú funkciu textu pri umeleckom preklade, ako o tom hovorí tento významný bádatel' odborných a literárnych textov: „Die Übersetzung der Realien in Romanen muss die Funktion haben, die literarische Qualität des Originals zu erhalten."15 Ide o široký okruh problémov prekladania historických románov z hladiska cirkevných reálií, ked treba zachovat nielen národnú a historickú špecifickost̉ diela, no predovšetkým náboženskú stránku konkrétneho spoločenského poriadku zobrazovaného umeleckým spôsobom. To sa deje aj prostredníctvom niektorých cirkevných reálií, ktoré sa úzko viažu na prelomové obdobie 17. a 18. storočia v ruských dejinách: никонианин - nikonovec v obidvoch prekladoch románu Peter I., pričom renomovaná prekladatelka M. Ličková nedávno ocenená prezidentom SR za celoživotnú prácu - ponecháva v pozn. pod čiarou i autorskú vysvetlivku, že išlo o prívržencov cirkevnej reformy, ktorá sa viaže $\mathrm{k}$ menu ruského patriarchu Nikona $(1605$ - 1681) a viedla $\mathrm{k}$ rozkolu v ruskej pravoslávnej cirkvi - reforma sa začala 19. februára 1651 (v moskovskej tlačiarni vydanie liturgikona / bohoslužobnej knihy - Služebnika). Tí, ktorí s reformou trvajúcou za patriarchátu Nikona $(1652$ - 1656) nesúhlasili a ostali pri starej viere, sa označujú v knihe niekolkými výrazmi - všeobecne sú to staroverci. Раскольник - rozkolník, staroverec, bezpopovec, staroobradník. Zatial čo reália бесnоповеu - bezpopovec (M. L.) - poustevník (J.H.) sa viaže tesne k obdobiu rozkolu, pacmpuza sa spája napr. už s menom Grišku Otrepieva v období smuty a pacnon - vyskočený kňaz (M. L.) bývalý pop (J.H.) tiež nie je tak tesne spojený s rozkolom. Celkové porovnanie reálií v prekladoch ukazuje, že lepšiu adekvátnost̉ pri cirkevných reáliách dosiahol J. Hulák

13 Porov. tamže, s. 19

14 „Ak máme pred sebou problematické miesta textu, musíme premýšlat o tom, aký vplyv má všeobecná funkcia textu na funkciu týchto miest v texte." KUßMAUL, P.: Verstehen und Übersetzen. Ein Lehrund Arbeitsbuch. Tübingen: Narr Verlag, 2010, s. 163.

15 „Preklad reálií v románoch musí mat funkciu, aby sa zachovala literárna kvalita originálu.“ Tamže, s. 163. 
než M. Ličková. Obidvaja prekladatelia sú $\mathrm{v}$ súčasnosti považovaní za vzor statočnosti za prácu vykonanú v časoch normalizácie, ved’ M. Ličková bola i ocenená nielen za početné preklady, no i za prejavené politické postoje v období normalizácie vysokým slovenským štátnym vyznamenaním $\mathrm{v}$ tomto desatročí prezidentom republiky, i ked’ niektoré prekladatel'ské riešenia obidvoch uvádzaných osobností českého a slovenského prekladatel'stva z ruštiny môžu vyvolávat pochybnosti. Záverom možno ešte zdôraznit, že predovšetkým J. Hulák vo všetkých porovnávaných prekladoch prejavuje orientovanost̉ na čitatela, teda nie je pod hypnózou ruských originálov ako iní prekladatelia diel s výraznou lexikou ruských cirkevných reálií.

\section{Literatúra:}

HRDINOVÁ, E. M.: Kultura v procesu překladu. Olomouc: Univerzita Palackého v Olomouci, 2017.

HRDINOVÁ, E. M.: Von drei translatorischen Nüssen des Aschenbrödels. Zeitschrift für Slawistik, 63 (2018), s. 338 - 350.

KUßMAUL, P.: Verstehen und Übersetzen. Ein Lehr- und Arbeitsbuch. Tübingen: Narr Verlag, 2010.

STOLZE, R.: Fachübersetzen - Ein Lehrbuch für Theorie und Praxis. Berlin: Frank \& Timme, 2013.

ŠVAGROVSKÝ, Š.: Gréckobyzantský rítus na území Slovenska. Slavica Slovaca, 33, 1998, č. 2, s. $97-108$.

TELLINGER, D.: Kultúrne otázky prekladu umeleckej literatúry. Košice: Typopress, 2005.

VYCHODILOVÁ, Z.: Několik poznámek k překladu religiózní literatury. In: LEPILOVÁ, K. (ed.): Rossica Ostraviensia '96. Lingua rossica in sphaera mercaturae. Ostrava: Filozofická fakulta Ostravské univerzity, 1996, s. 247-251.

WITTE, H.: Die Kultukompetenz des Translators: begriffliche Grundlegung und Didaktisierung. Tübingen: Stauffenburg Verlag, 2000.

\section{About the author Dušan Tellinger \\ independent researcher, Košice, Slovak Republic tellinger.dusan@gmail.com}

